\title{
Integration and Utilization of Network Course Resources for University Teachers
}

\author{
Xingzhi PENG, Wei LI, Ruijin ZHOU, Qiang FANG, Qianyu CHEN, Mei LI
}

Henan Institute of Science and Technology, Xinxiang, China

\begin{abstract}
Network course resources are a mew development formation under the information technology condition. University teachers as the positive factor of network resources integration, how to make full use of modern information technology and thinking mode of pedagogy to turn shared resources into curriculum resources and make full use of it has become an worth discussing important problem under the background of the current university. Based on the university teachers how to integrate and use network course resources, some strategies has been put forward.
\end{abstract}

Index Terms: University teachers; network course; integration and utilization

(C) 2012 Published by MECS Publisher. Selection and/or peer review under responsibility of the International Conference on E-Business System and Education Technology

\section{Introduction}

Network course resources is a course resources which using communication equipment of computer system to spread and network software to manage. Curriculum resources have been realized by computer network to the greatest degree sharing. It is no doubt that it has provided guarantee for university teachers to integrate curriculum resources. How to make full use of modern information technology and thinking mode of pedagogy to turn shared resources into curriculum resources and make full use of it has become an worth discussing important problem.

\section{Conditions for university teachers to integrate and use network education resources}

\section{A. Curriculum Accomplishment and Ability Structure}

Curriculum accomplishment of teachers includes three aspects: spirit field, knowledge scope and psychomotor domain. Teachers' curriculum accomplishment directly related to the effect of curriculum resources integration and utilization. After have certain curriculum accomplishment, what's more, university teachers should further consider to promote information literacy in their subject teaching. Make disciplines and learning process as a

* Corresponding author.

E-mail address: Xuelin20070101@163.com 
whole. So they should have IT capability, teaching design ability, and the ability of using resource integration and information technology in teaching.

\section{B. Advanced Teaching Idea}

Takes modern educational teaching theory as guidance and relies on modern information technology, it not only make a challenge to traditional teaching mode, curriculum and textbook, but also make a challenge to traditional educational thought and educational concept which peoples have accustomed. Modern educational concept emphasizes that modern information technology and latest educational theory should be used in teaching to optimize teaching results. It emphasizes quality education and creative talents should be cultured. And it emphasizes the learning needs and learning characteristics of learners should be studied and the individual needs of learners should be needed. The establishment of modern education concept is the requirement of modern society to education and an inevitable response of education faces rapid development society. It is the basic foundation for our study and practice, and also the guiding ideology of teachers' educational teaching activity.

\section{Network Environment and Resource Sharing Platform}

In order to promote the process of university information resources co-construction and sharing, so far, the government has input more then one billion to build campus network and digital campus. Network almost has been connected to every corner of campus. National information network, education network, and national university internet have become the best platform for teachers and students to obtain all kinds of education information. Traditional teaching and network teaching together be used in every university basically realized.

In the process of education information and modernization, every university has organized and developed the construction and use of network teaching resources. To construct excellent course, network course, subject website and so on. Some university has built network teaching resources and has been popularization and application in modern teaching. University teachers only take themselves into the environment of powerful internet and resources joint building and sharing that the integration and utilization of network education resources will really become possible.

\section{Strategies for university teachers to integrate and use network education resources}

\section{School-based Curriculum Resources}

At present, university network curriculum resources have three types: the first is the references and retrieval of library information service; the second is multimedia course information resources which include multimedia material, all kinds of CAI courseware, network course and so on. The third is all kinds of tool resources and plenty of internet resources which be formed, analyzed, treated, transferred and used that comes from course information resources. Before to integrate network course resources, resource database should are set up by teachers. The resource database can provide resource for students to study.

The curriculum resources selection should reflect the priority principle. On one hand, the effect should be preferred. It is namely that the resources have conducive to realize curriculum objectives and have help to reach the teaching goal. The other hand, it is using first. It says that the resources can be used immediately after find. The best combination of curriculum resources and curriculum content is the key of integrating and using curriculum resources. In order to effectively full play to the effect of curriculum resources, teachers need to do some work well such as the independent development of curriculum resources and the depth or width of curriculum field.

Teachers should be based on the school tradition and the reality of the situation to expand and integrate curriculum resources. Only the students' characteristics and the practical of own courses have been combined, and the essences of shared resources have been draw, teachers can make others curriculum changes into their own.

\section{E. Taking Morden Information Technology As the Integration Tool of Network Course Resources}

The development of modern information technology is breaking the space-time restriction. This makes a possible for curriculum resources are broad communion and shared. University teachers could sharing or obtain network course resources by the next ways: 
One hand is search engine. Search engines are the system with providing retrieval service. Another is online communication platform, such as the BBS, mail, QQ, etc. the third is CNKI. CNKI is the biggest information and the valuable Chinese website globally. The resources from CNKI have a high value and collection value. It can be used as academic research and scientific decision-making basis. The fourth one is popularity and authoritative website. Generally, the information published by authoritative organization or famous institutions, especially government organization, famous research institution or the document information published by university.

Teachers find information according to the professional attribute or categories to obtain relevant website access to information. After teachers search for much curriculum information resources, they must do some work with them, such as reforming, processing and reapplication. Modern information technology plays a role of development tool in the integration process of large useful information. Information technology using real showed, fluent transmission, proper effect to original manuscript embody educational idea, education methods and educational content. The final goal of information technology used in integrating educational resources is to culture students' exploration ability, the ability of discover problems and solving problems and culture creative thinking ability.

\section{F. Seeking Cooperation, Multivariate Combination}

Cooperation is more and more believed one of the key factors to the teachers' professional development. Good cooperation relations will do a best for playing teacher's individual expertise, expanding teacher's personal professional knowledge and skills, training tacit agreement of cooperative processing academic affairs and mutual support colleague relationship. All this will provide conditions and help for teachers doing real sense integration with curriculum resources.

In the information age, cooperation is the important form for modern teaching and learning. A teacher must have successful cooperation ability with other teachers or professional staff. This is an important qualities and experience background for teachers to culture learners' cooperative ability.

In the process of network course resources integration and utilization, cooperative relationship not only exists in teachers' nut also be happened with the other workers. This is good for the development direction of network education resources integration, management objectives. Network managers are responsible for the maintenance of network hardware system and the development or shopping of resource management system. Educational technology staff is the instructor and unhelpful for teachers to design teaching, realize independent development or secondary development.

\section{Problems Should be Paid Attention in Integrating and Using Network Course Resources}

\section{G. Pay Attention to Temands of Students}

The objective of integrating and using course resources is to enhance the creative spirit and practical ability of students, and construct a learning platform for student. In the cross of integrating and using course resources, learning situation and learning effect should be concerned in time. Expedite information feedback mechanism also should be set up. The teachers can know the effects which curriculum after be integrated by having an informal discussion with students or instructors. Some measures should be used to solve the problems that who have been find in informal discussion. Only in this way, it will meet the require of students in the cross of resource sharing and using.

\section{H. Establishing Sharing Consciousness}

Some problems often are met in practical operation. Such as when landing some schools teaching resource database, it often tell us that we have no authority to see. Because of network environment, resources accreditation, application platform, and so on, real sharing can not be realized among colleges. Individual teachers, the resource that developed by themselves most be used by them own. They are reluctant to provide for the others.

Excellent resources sharing idea should be established by the university teachers that who have modern education concept. The relation of sharing and competition should be correctly handled. They should set up whole idea for providing whole level of teaching and benefits from running school. The importance and 
necessity of resource sharing should be fully recognized. Some mechanisms and instructive regulations were made by relevant departments are the power for arousing teachers' enthusiasm and initiative. The change of teachers' idea and the build of sharing consciousness are more important for curriculum resources construction and sharing.

\section{Improving Self Continuously}

Most university teacher graduated from normal university. They all have received systemic training with educational teaching theory and methods, and pre-post information technology skill training. But they lack of theoretical guidance in effective integration with resources teaching design and information technology with subject. It causes that Information technology can not be real effective transferred to classroom teaching by teachers. In the build of network teaching resources, technical design usually is pay attention to and teaching design usually be neglected. Both educational and pertinence of resources are very weak. It is difficult to meet the require of modern teaching.

To build a learning community of teacher self-promotion continuously and make system training plan are also a further study problem for relevant departments. The source of teachers' constant progress and development is the internal learning motivation. The external training will play a role through them finally.

\section{Conclusions}

The integration and utilization of network course resources is a very practical work. There is no available mode can be referenced. Teachers should make full use of their own teaching wisdom and new curriculum idea to guide teaching work. According to the actual situation of school and curriculum, teachers develop their creative work. At the same time, in order to avoid unnecessary repeated work, teachers should pay a more attention to all kinds of experience and methods.

\section{References}

[1] Cao Weizhen, "Study on integration of network education resources in local university", E-Education Research, 2007, vol, 8, pp: 32-35.

[2] Zhang Xiaolan, "The theory and method of integration between information technology and curriculum", Beijing: National Publishing House, 2004.

[3] Liu Dehua, Xie Juan, "Upon teachers' development of course resources in higher learning institutions", Journal of Ningbo University(Educational Science Edition), 2009, vol, 2, pp: 1-6

[4] Zuo Xiaomei, "Study on disorder and countermeasure about the effective integration between information technology and subject teaching", Modern Distance Education, 2006, vol, 6, pp: 65-68.

[5] Tang Linfei, "The conformity and utilization of curriculum resources in school-based curriculum development", Journal of Hangzhou Medical College, 2005, vol, 4, pp: 31-34. 